\title{
紙パルプ技術の予測
}

\author{
東京農工大学 大 江 礼三郎
}

\section{Forecasting on Pulp and Paper Technology}

\author{
Raysabro Oye \\ Tokyo University of Agriculture and Technology.
}

本日は，「21 讨紀への展鼠一紙パルプ技術の未来」 という，大変に大きな課題で，パネル講演を開催する ことに相成りました。たまたま，私が進行役的な役割 を和引き受けすることになりました経緯を説明致した いと存じます。

昭和 50 年 4 月に, 紙パルプ技術に関係の深い有志 が集まりまして，紙パルプ技術尒测研究会を発足させ， 51 年と 54 年の 2 回にわたり，デルファイ法による紙 パルプ技術の子测調枯を行って沶ります。じらい, 数 年を経まして，紙パルプを取卷く瓌境がかなり変化し て参りました。そこで57 年に，第 3 回の紙パルプ技 術予湘を行うこととなり，技術予测研究会にシナリオ 委員会を設谓，14名の委员によって作業を進めて参 りました。たまたま，私がまとめ役を仰せつかりまし たので，本月，この席にて報告川し上げる次第であり ます。

予測調查の項目と簡䇤な結果は, 大会要旨集に挙げ てありますが，揃細は「2001 年の紙・パルプ」と題 した単行本に揭载されて和ります。ここでは.今回の 調查の梗概を述へ，問題点につきまして，3名の講師 の方から括を話くことにした背景に触れたいと存じ ます。

紀元 2000 午は今から 16 年後になりますが，その時 点で我が国の紙パルプ花箖がどのよらな形になってい るであろらか，紙パルプにかかわりのある我々にとっ ては，大変㸚摠りのことであります。6 年先に，今と 同じページ数の新聞を読んでいるであろうか，部厚い 電話帳を繰っているであろらか，事務所の帳簿はどう なっているであろうか，今と同じダンボール箱が使わ れているであるらか，小舀「紙の消兄る日」にあるよ らに原木の手当は本当に大丈夫なのであろらか，など 昭和 60 年 (1985) 1 月
心配の種は多いのであります。

「2001年の紙・パルプ」に書きましたように，紙パ ルプ産業は, 過去において常に危機感に包まれてまい りました。これをトワイライト・シンドロームなどと シニカルな表現を致しましたが，事実，幾度も危機が あったわけであります。それを我々は技術をもって解 決してまいりました。いささか古くなりますが，アカ マッの亚硫酸パルプ化, 溶解パルプヘの L材の利用, LBKP による上質紙の製造，チップの大量海上輸送， 南方材, ユーカリ材の利用, 各種の公害対策, 省エネ ルギー対策, 近くは新聞用紙への新聞古紙の大量配合, クラフト蒸解へのアントラキノンの利用など, 海外に 比べ特徴的な数々の対応が行われてまいりました。

しかし，現在も，ニューメディアの台頭による情報 化社会の進展に伴う紙の役割の変化, 原木問題, 輸入 紙の圧力など，心配の種はつさないのであります。

しかしながら，ミネルバの梟（ふくろう）は黄昏に 翔ぶと申します。不安があってこそ智恵を働かせ，技 術をもって，我が国の紙パルプ産業を発展させてゆく ベきなのであります。その方向の模索が，技術予測の 目的であります。

さて，技術予測の内容でありますが，31の事項に わたって設問を作成して扣ります。各設問について, 楽観, 中間, 悲観の 3 つのシナリオを用意し, それぞ れのシナリオが生起しそらな確率を回答して頂く方法 で調盾を致しました。デルファイ法による予測の場合 は，ある事象が実現する時期をたずねるため，解答が 1 つになりますが，シナリオ法でこのような四答方法 に致しますと, 楽観, 中間, 悲観のそれぞれに重みづ けをする形になりますので，回答はし易くなりますが， 集計結果には差が出難くなります。予測調查のアンケ 
一トの対象は約 300 名で，185名の方から问答を戴き ました。この種の調查としては，十分な回答摔であり ました。このよらな子測調㭗は，設問のシナリオによ って方向づはありますが，結局は回答者の与論調査 に近いものであり, 要は, 現在, 紙パルプに関係の深 い有識者の方々が，2000年の紙パルプをどら考光て いるかといらことになります。

31 の設問は，(1)需要構造，(2)製品供給，（3)技術芇 新，(4)経営における技術戦略の 4 つに大別致しており ます。

次に設問の題目と，それに対する楽観的(A)，中間的 (B)，悲観的(C)シナリオの生起確率を示します。 (需要構造)

(A) (B) (C)

（1）世界の紙，板紙の需要 $25 \% \quad 47 \% \quad 27 \%$

(2) わが国の紙, 板紙の需要

\begin{tabular}{llll} 
& $14 \%$ & $46 \%$ & $40 \%$ \\
(3) ニューメディアと紙 & $40 \%$ & $39 \%$ & $20 \%$ \\
(4) 印刷, 出版用の紙 & $29 \%$ & $45 \%$ & $26 \%$ \\
(5) 包装資材としての紙 & $19 \%$ & $40 \%$ & $41 \%$ \\
(6) 段ボールの需要 & $40 \%$ & $37 \%$ & $23 \%$ \\
(7) 複合材としての紙 & $34 \%$ & $39 \%$ & $27 \%$ \\
(8) ディスポーザブル製品としての紙 & \\
\multicolumn{4}{c}{$38 \%$} \\
\hline
\end{tabular}

(9) 紙, 板紙の需要構造の推移

$24 \% \quad 44 \% \quad 32 \%$

（製品供給）

(10) 需要, 供給, 原料バランス
A $2 \%, \mathrm{~B} 5 \%, \mathrm{C} 13 \%, \mathrm{D} 11 \%$,
E $23 \%, \mathrm{~F} 25 \%, \mathrm{G} 14 \%, \mathrm{H}, 7 \%$

(11) 製品輸入と国内生産構成比

\begin{tabular}{|c|c|c|c|c|}
\hline & & $19 \%$ & $44 \%$ & $37 \%$ \\
\hline (12) & 国産針葉樹材の供給 & $15 \%$ & $47 \%$ & $38 \%$ \\
\hline (13) & 国産広葉樹材の供給 & $25 \%$ & $50 \%$ & $25 \%$ \\
\hline (14) & 輸入針葉樹材の供給 & $28 \%$ & $42 \%$ & $30 \%$ \\
\hline (15) & 輸入広葉樹材の供給 & $34 \%$ & $39 \%$ & $27 \%$ \\
\hline (16) & 南方造林 & $27 \%$ & $49 \%$ & $23 \%$ \\
\hline \multirow[t]{2}{*}{$(17)$} & \multicolumn{4}{|c|}{ バイオテクノロジーと木材生産 } \\
\hline & & $19 \%$ & $42 \%$ & $39 \%$ \\
\hline (18) & 紙用古紙の供給 & $50 \%$ & $37 \%$ & $13 \%$ \\
\hline (19) & 板紙用古紙の供給 & $35 \%$ & $42 \%$ & $23 \%$ \\
\hline (20) & 古紙処理技術 & $44 \%$ & $31 \%$ & $25 \%$ \\
\hline \multicolumn{5}{|c|}{ （技術革新） } \\
\hline (21) & 高歩留パルピング & $35 \%$ & $40 \%$ & $25 \%$ \\
\hline (22) & 化学パルピング & $26 \%$ & $42 \%$ & $33 \%$ \\
\hline & \multicolumn{4}{|c|}{ パルプスラリーの高濃度化 } \\
\hline
\end{tabular}

$31 \% \quad 43 \% \quad 26 \%$
(21) 抄紙技術
$25 \% \quad 42 \%$
$33 \%$
(20) 紙の軽量化之问证料化 $31 \% \quad 44 \% \quad 24 \%$
(26) 中性抄組
$47 \%$
$26 \% \quad 27 \%$
(27) 省エネルギー
$31 \%$
$49 \%$
$29 \%$
(28) コンピュータシステムの筫入 $25 \% \quad 59 \% \quad 17 \%$

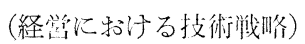

$\begin{array}{llll}\text { (29) 技術開発力 } & 30 \% & 41 \% & 29 \% \\ \text { (30) 技術の人的要䋆 } & 31 \% & 37 \% & 32 \% \\ \text { (31) 製紙企栄の技術们展開 } & 35 \% & 36 \% & 29 \%\end{array}$

技術子測であっても，将来の紙，板紙の星执よび需 要構造がわがらないと, 技術们刘纫が成立たないので, まず，需要了测を行っております。袖間 1 ，「世界の 紙，板紙の需要」，2。「わが同の紙，柲紙の需要」抒 よび 10.「需要，供給，原料バランス」がそれであり ますが，需要の伸びは $2.3 \%$ 以下という結果が得られ ました。これは産構審の尒測値を下回った数字であり ます。

設問 3 .ニューメディアと紙は，令回の子测作籍の 1 つの柱である外部インパクトの問題であります。こ れについては, パネル講湖で，ニューメディアに造詣 が深く，活発に活動されて扔られる博袁坚メディアセ ンター室長の小宮山さんに括望を頂くことになって拉 ります。また日本紙パルプ觕本の小呈さんからも，こ の問題にコメントがあるものと存じます。予测調查の 結果としましては，ニューメディアと紙とは其存関係 にあるという比較的楽観的な見解が多くありました。

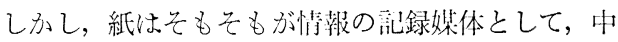
国で 2000 年前に生まれたのであります。現在，情報 の記憶容量の点では，磁殡テープなどに比ぶべきもあ りません，また包装もバルク輸送，省資源的包装が進 行しつつあります。このような㭙に，非常に大きな重 みをもってくるのが，製楒輸入であります。54年の 予測の折も，約 $80 \%$ の人が 1996 年には製品輸入が 10\%になると予测致しました。今回の設問 10 .「需要, 供給，原料のバランス」でも同樣な結果が得られまし た。かりに年率 $2.3 \%$ の需要の伸びがあっても，製品 輸入が $10 \%$ になるのであれば，輸出が增えない限り 実質成長は $1.7 \%$ になすす。しかも，国際競争力の ある分野での競合となると，技術面で大きな影響がで てまいります。本日は，紙，板紙の流通など需要問題 に精通された日本紙パルプ商束の小室さんに色々な角 度から招話を承ることになっております。

原料問題でありますが，もし需要増が年率 $2 \%$ そこ そこで，古紙の利用，輸入パルプの增加が見込まれる と，原木問題は菖ほどには深刻でなくなります。むし 
ろ增大しつつある网内資泊をそのままに，外材を輸入 することに国際非難が生じるか子知れません。

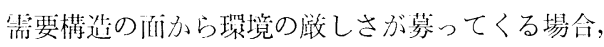
これを打破し，我が国の紙パルプ座業が繁栄するため には, 他国の紙パルプ座業に卓越した技術力が要求さ れます。省資源, 省エネルギ一, 品铮向上に色々と課 題がありますが，技術宁测の維果としては，プロセス は大体, 現在の延長で進行し, 省エネルギー, 自動化 は益々進步するということになりました。

しかし，一口に技術開発といっても，技術開発に当 るものには，現実的に仙々な悩又，生臭さ，空しさが つきまとうのであります。本日は，紙パルプに拉ける 技術開発で豊宫な経騟を挆持らの元巴川製紙の武さん
に，その一端と今後の技術開発のあり方について括話 を頂くことになります。

これまでの技術予測は，どうしてもハードウェア一 辺倒になりがちでしたので, 経営に稀ける技術戦略と いら項目で，人の問題を取り上げました。その折，ア ンケートのコメントとして寄せられた御意見として， 「技術は人なり。われわれ技術者は，化学，機械とい った領域に捉われず，他産業の知恵を吸収する業際的 努力を重ねる必要がある。との御指摘があり，大い に共鳴致しました。

それでは, ニューメディア, 需給問題, 技術開発の 3 命題について, 今後の紙パルプと将来について, 各 講師から講演を頂くことに致します。 